Winter 2010

\title{
Sculpted Landscapes: Art \& Place in Cleveland's Cultural Gardens, 1916-2006
}

Mark T. Tebeau

Cleveland State University, M.TEBEAU@csuohio.edu

Follow this and additional works at: https://engagedscholarship.csuohio.edu/clhist_facpub

Part of the History Commons

How does access to this work benefit you? Let us know!

Publisher's Statement

Copyright 2010 George Mason University. Available on publisher's site at http://www.jstor.org/ stable/25790361.

Original Citation

Mark T. Tebeau, "Sculpted Landscapes: Art \& Place in Cleveland's Cultural Gardens, 1916-2006," Journal of Social History 44 no. 2 (2010): 327.

\section{Repository Citation}

Tebeau, Mark T., "Sculpted Landscapes: Art \& Place in Cleveland's Cultural Gardens, 1916-2006" (2010). History

Faculty Publications. 4.

https://engagedscholarship.csuohio.edu/clhist_facpub/4

This Article is brought to you for free and open access by the History Department at EngagedScholarship@CSU. It has been accepted for inclusion in History Faculty Publications by an authorized administrator of EngagedScholarship@CSU. For more information, please contact library.es@csuohio.edu. 


\section{SECTION 1 \\ ARTS AND CITIES}

\section{SCULPTED LANDSCAPES: ART \& PLACE IN CLEVELAND'S CULTURAL GARDENS, 1916-2006}

By Mark Tebeau

Cleveland State University

The long-dormant Cleveland Cultural Gardens flowered in 2006, with the unveiling of a 10-foot memorial to Mahatma Gandhi as the centerpiece of the newly developed India Cultural Garden. Accompanied by dancers and a small but boisterous crowd the new Garden reflected an ambitious effort to revitalize the Cleveland Cultural Gardens-a complex of twenty-four formally landscaped public gardens that run in a line through a narrow city park that abuts the city's primary cultural district. Begun 90 years earlier, the internationally-unique Cleveland Cultural Gardens appeared to be in the throes of a complete phoenixlike rebirth from ruins. As the city welcomed the new efforts, many observers took a measured view, recognizing the long struggle to keep the Gardens' "cultural harvest from dying on the vine." Shortly after the India Garden opened, Cleveland Plain-Dealer columnist Phillip Morris contrasted the India Garden's vitality with the "American Garden" located just across Martin Luther King Drive. He reported that the American Garden "simply wept. Lincoln is missing from the park, as are John Jay and Mark Twain.... Only Booker T. Washington, the noted author and educator, stands sentry. But he looks tired. The base of his bust is cracked and his pedestal is tilting. It seems only a matter of time before wind, vandals, or dogs send him rolling down onto Martin Luther King Jr. Drive." In highlighting decay amidst revitalization, in contrasting the India Garden with the American Garden, Morris ruminated not only on the condition of the Gardens but also on the state of the city more broadly. Were these places-Cleveland and its Cultural Gardens—dying or recovering? ${ }^{1}$

Exploring how the Cleveland Cultural Gardens transformed from an international symbol to a desecrated cemetery to a symbol of hope reveals the interrelation between art and place. Conceived more ambitiously than most isolated monuments as a unified complex of formal landscape gardens, the Cultural Gardens were living "memory theaters." Beginning in 1916, migrants to Cleveland and their descendents constructed the expansive public art landscape to negotiate nationality, ethnicity, and American identity. Drawing largely upon the invented traditions of nineteenth-century European nationhood, the Gardens expressed such collective identity by encoding their ideals in a variety of formsstones, statues, fountains, inscriptions, and plantings. The Gardens became a dynamic liminal space, mediating between the commemoration of the dead and the aspirations of the living. Their vitality, as with all such memorials, depends upon audiences educated in the meaning and significance of their symbolic codes. At the height of the Great Depression, this iconographical narrative attracted 
Figure 1

Unveiling of Gandhi Statue

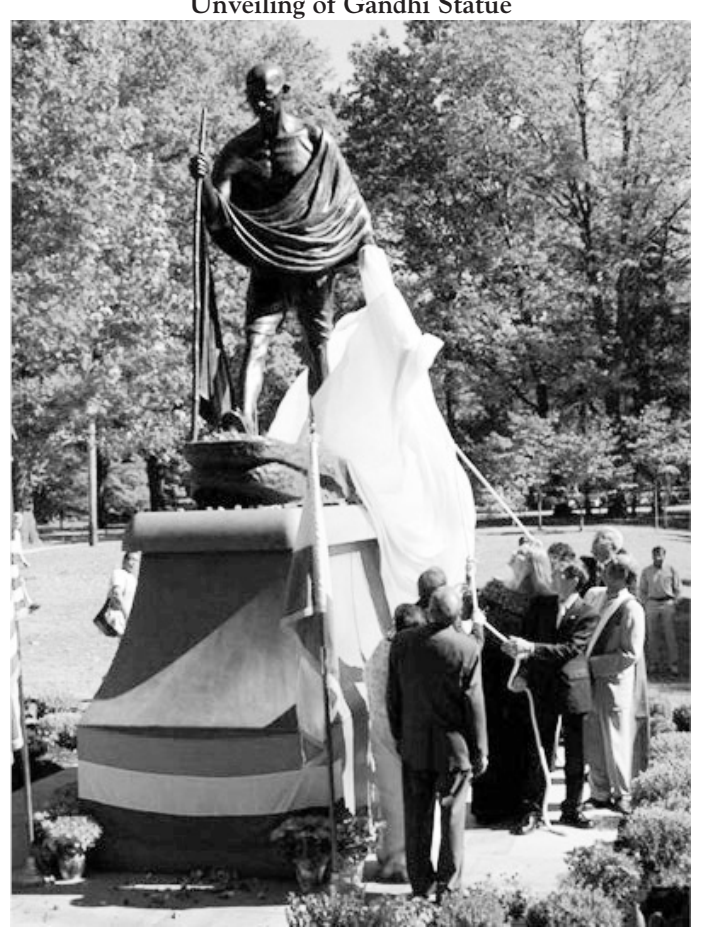

In 2006 the India Cultural Garden unveiled a 10-foot memorial to Mahatma Gandhi at its center; the India Garden was the first addition to the Cultural Gardens in more than 20 years. Credit: Kyle Roth

hundreds of thousands of visitors to the Cultural Gardens, which emerged as an internationally-recognized symbol of peace and helped to define Cleveland as a place. $^{2}$

To the degree that the Gardens embodied their home city, they function like other works of public art and monuments, providing a lens through which to explore larger themes, revealing changing community values, power relations, institutions, and historical change. Yet, defining the Gardens by any single code or historical moment would mischaracterize them, minimizing the degree to which art projects (and gardens) develop a new character as they age, mature, die back, and sprout anew. That monuments take on new meanings and identities with time recommends that we take account of their entire life course, from their birth to death. ${ }^{3}$ And, indeed, memorials and monuments commonly disappear from our consciousness, as Viennese novelist Robert Musil radically suggested when he wrote that "there is nothing in the world as invisible as monuments," pointing to the many ways in which monuments lose their cultural legibility. ${ }^{4}$ Perhaps, then, we should not be surprised that the Cultural Gardens eventually went dormant. In the 1970s, they all but disappeared, physically and metaphorically, from the city's consciousness, lying fallow for many years, with their significance seemingly erased completely from memory. Seen in this light, recent efforts to recover the Gardens can be viewed as remarkable, if not futile. This essay uses the Cleveland 
Cultural Gardens as a lens through which to explore how have art and place have intersected over time: How did communities negotiate questions of national, ethnic, and American identity, and embed those identities into the vernacular landscape? To what degree is it possible for diverse groups to find and enact a common language when they create public art? Perhaps more pointedly, can communities create inclusive public art that stands up to the changing currents of history? Can public art ever transcend its place-both in terms of geography and history? Can it remain vital beyond the life of its creators, and, if so, what form does that new life take?

The Cultural Gardens were developed in Cleveland's Rockefeller Park, a bequest from the oil magnate John D. Rockefeller in 1897 that was part of the city's broader efforts at beautification. Designed by a protégé of Frederick Law Olmsted, the 276-acre Park was emblematic of an era of urban park development, city beautification, and cultural uplift. Located six miles east of the Cuyahoga River and perpendicular to Lake Erie, Rockefeller Park sits within the lower part of the steep-sloped, Northward flowing Doan Brook watershed. The park surrounds the brook, whose boundaries engineers had shaped with stone channels, gradually drying out low-lying wetland and pushing a lengthy stretch of the brook into underground culverts. Long and narrow, the park had a carriage promenade tracing the path of Doan Brook, sitting between steep embankments that are traversed by parkways flowing over architecturally ornate bridges. With Olmsted's influence written onto the landscape, the Cultural Gardens drew upon City Beautiful principles. Beaux Arts ornament and statuary, for example, became a prevailing motif of the Gardens, although the abundance of architectural work shifted the park away from the naturalist impulses toward the didactic formalism of nineteenth-century rural cemeteries. ${ }^{5}$

In 1916, Leo Weidenthal, a reporter for the Cleveland Plain-Dealer and Shakespeare devotee, planted the first seeds of the Cultural Gardens when he inaugurated the Shakespeare Garden as a way of elevating cultural life in Cleveland. Drawing upon the global commemoration of the tercentenary of Shakespeare's death, Weidenthal's efforts referenced broader attitudes about the ascendancy of Anglo-Saxon racial identity, an outpouring of sympathy for Britain's entry into World War I, and the resurgence of centenary celebrations as vehicles for asserting collective identity. In a ritual replicated in Shakespeare gardens planted elsewhere during the tercentenary, Weidenthal created a sacred space by using plant materials that were literal embodiments of the playwright's work, such as a vine taken from the "traditional tomb of Juliet in Verona, Italy" and Sycamore Maples from the Great Birnam Woods of Scotland (the setting for Macbeth). Such centenary celebrations-commemorations tied to the 100-year anniversary of the births, deaths, and other moments in the lives of artistic and cultural figures - were part of the broad process of inventing national identity, the development of a historical consciousness in Western societies, and economic development through tourism. ${ }^{6}$

In 1926, following in the wake of the Shakespeare Garden, Weidenthal cofounded the Cultural Gardens League (CGL) in an effort to create an organization and a landscape that would both embody and contain the pluralistic cultures of the Cleveland by drawing them together in common purpose. Cleveland was a fertile landscape for such a project. Not only was the city the nation's fifth largest in 1920, but also more than 30 percent of city residents had been born 
outside the United States. A decade later, over 60 percent of the population was foreign born or had at least one foreign-born parent. Immigrants had come to work in one of the world's most diverse industrial regions, with an economy that grew at a blistering pace of 10 percent yearly. Weidenthal-by then the editor of the local weekly Jewish Independent-built on the strength of the region's diversity by seeking collaboration with other of the city's ethnic leaders. His initial partners, Charles Wolfram and Jennie Zwick, represented progressive-era civic organizations, the Civic Progress League and American Equity League, each with ties to the city's immigrant communities, including newly formed interethnic alliances forged by a Mayor's unity commission during World War I. The CGL sought to "promote better understanding" by memorializing cultural heroes in formally landscaped gardens. Its mission statement advanced "the cause of human brotherhood and democracy by encouraging and developing sympathetic understanding." The CGL wanted to "perpetuate" the contributions "made to the advancement of civilization and the course of Peace by the cultures of these several groups" and in so doing "to enrich the lives of all American citizens." Moreover, the organization wanted to create a model that would be a beacon. It advocated for "peace and brotherhood" that transcended Cleveland, providing a model for international cooperation, a mini "League of Nations" as many would later claim. ${ }^{?}$

The organization's founders engaged debates about immigration and American identity that raged in the 1920s, recommending the Gardens as an alternative to prevailing attitudes. Weidenthal, in particular, emphasized diversity as a key element of the Gardens, proposing a "multicultural" vision of America some 50 years before the concept would gain wider currency. In the official history of the Gardens, Weidenthal articulated a philosophy of "one out of many." He argued that "True cultures impose no barriers of race or creed. In fact, their influence is toward mutual understanding and wider sympathy." Weidenthal rejected the melting pot notion first articulated in 1908 by Israel Zangwill in his play of the same title, but he adopted Zangwill's belief that art and literature could reshape society, especially Zangwill's belief that Shakespeare could act as civilizing force. Weidenthal and his colleagues offered a corrective to the National Origins Act, which had established quotas for immigrants and was based, in part, in Eugenics. The Garden's founders emphasized the distinctiveness and importance of immigrant culture by drawing upon the centenary celebrations that honored elite cultural figures and by asking the city's ethnic elite-business, political, and social leaders-to serve as delegates to the CGL. By rooting the Gardens in the contributions of ethnic elites, the League's founders also offered a counterweight to the growing influence of mass culture, an alternative locus of identity for recent immigrants. As with the City Beautiful movement, high culture became an agent of change- a way to civilize working-class immigrants, to educate immigrant children, and to challenge prevailing nativist sentiments. The Slovak Garden Delegation's statement of purpose revealed the multiple audiences to which the gardeners spoke, "[the Garden is] a vivid testimonial of our national maturity and education, not only to native Americans and other nationality groups, but to our offspring, to whom we desire to leave this beautiful heritage." ${ }^{8}$

The League built an organizational structure that balanced brotherhood against difference, with care to accentuate and promote diversity—of perspective and ethnic origin. The federated institutional structure of the Cultural 
Gardens League reflected Weidenthal's "one out of many" approach. The CGL selected delegations from leading cultural organizations, usually a church or association, from each of the city's ethnic communities. Each delegation sent two representatives to serve on a board that elected officers charged with administering the Gardens. The CGL held authority over designs and choice of sculpture proposed by delegations, which were charged with developing proposals for gardens, then funding and maintaining those spaces. The City Parks Department and Planning Commission also shaped the Gardens through its landscape architects who received and judged every proposal and architectural drawing. In 1936, after the Works Progress Administration began funding the gardens, Park Department oversight increased. ${ }^{9}$

Energized by the city's diversity and its economic well-being, Weidenthal's plan for a "panorama" of gardens that would "stand as a symbol of democracy and brotherhood" bloomed. In 1927, Cleveland City Council designated the section of Rockefeller Park where the Shakespeare Garden sat as "Poet's Corner" and further subdivided the park. Between 1930 and 1938, Council action formally established the Cleveland Cultural Gardens by authorizing fifteen Gardens along the sloping hillsides of Doan Brook. Local communities financed the Gardens through fund-raising events and with donations from businesses, ethnic organizations, churches, and individuals. International governments offered statues and money. For example, the Italian Garden League toured Italy seeking funding, eventually securing support from Mussolini, and the Greek government donated sculpture to the project. Ironically, economic depression may have provided the biggest boost. As early as 1935, the city of Cleveland began to subsidize their construction and also endorsed requests to the Works Progress Administration for garden construction. Eventually, the WPA funded much of the labor deployed in building the chain, financing approximately $\$ 650,000$, or more than half of the estimated total expenditures between 1926 and 1950.10

As they built Gardens, local ethnic groups embedded international cultural identities into the landscape, using organic and inorganic materials lade with symbolic meaning as relics of national identity. With its 1926 inauguration, the Hebrew Garden provided a model for how to integrate plant materials into a garden design. Dedicated "to Israel's singers, sages, and dreamers of dreams," the Garden represented the cultural accomplishment of Jews and promoted cultural Zionism. National and international civic and political leaders participated in opening ceremonies, planning botanical materials that connected the Garden to a Jewish Homeland. For example, in 1926, Hebrew-language poet Chaim Bialik, who was traveling the United States promoting Zionism, planted three "Cedars of Lebanon" in the Garden. One year later, Chaim Weizman, then President of the World Zionist Organization and later President of Israel, repeated the ritual, planting three additional cedars. He was accompanied on the dais by Weidenthal and Rabbi Abba Hillel Silver. Rabbi Silver led Cleveland's Temple Tifereth Israel, the largest Reform congregation in the world in 1927. Silver also would emerge as one of the leaders of the International Zionist movement, addressing the United Nations General Assembly in 1947, advocating for the creation of the state of Israel. Thus, the Hebrew Garden became directly and symbolically connected to broader Jewish cultural and political claims. Other gardens would also plant seeds, trees, or flowers (sometimes directly brought) from their homelands as a way to express communal identity and to define political boundaries. ${ }^{11}$ 
Figure 2

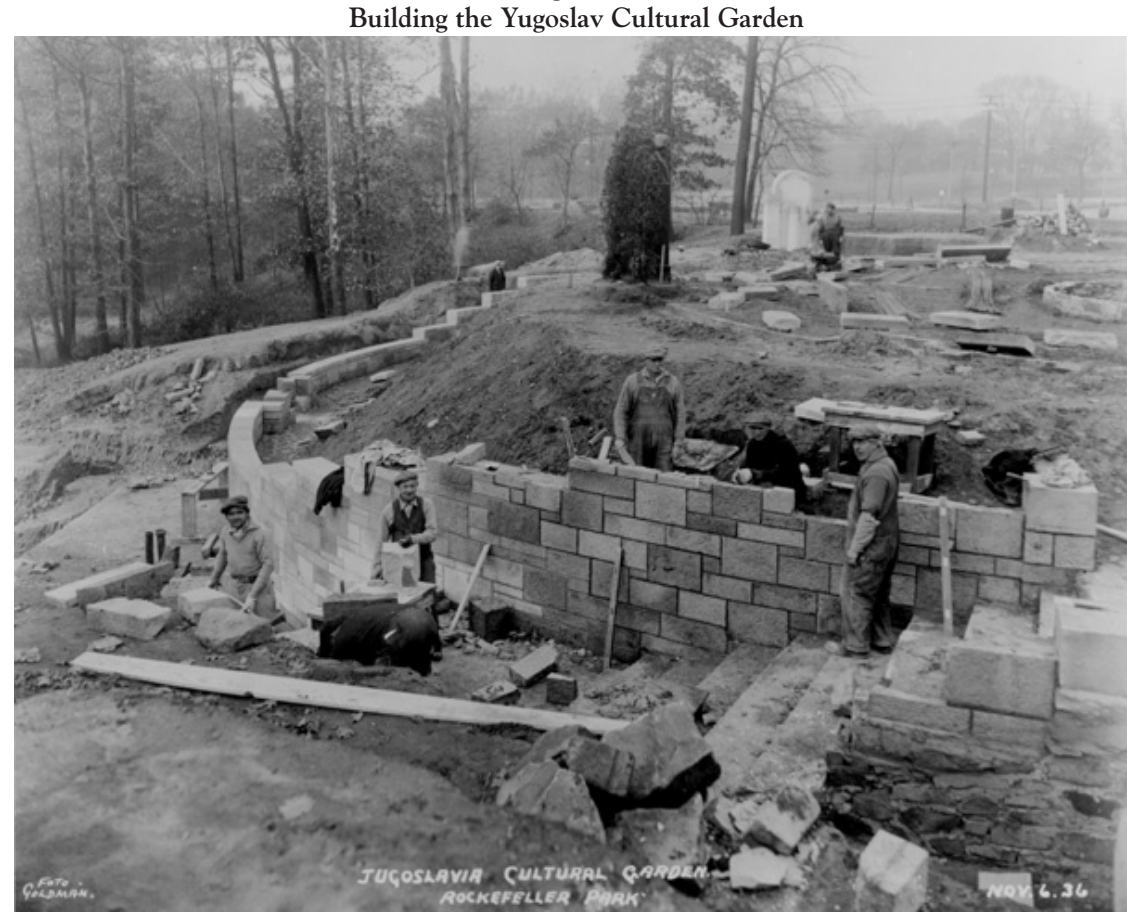

Much of the work on the Cultural Gardens was funded by the WPA in the late 1930s, as much as half of the entire cost. Local stone masons build the Yugoslav Garden in 1936. Credit: Cleveland Public Library

In addition to using plants, cultural gardeners used artifacts and architectural relics to make the gardens sacred. In the Italian Garden, for instance, the bust of Virgil stood on a column from the Roman forum that, according to the Cleveland Plain-Dealer, was made of Travertine stone "of which most Roman buildings are made." Also there was a granite boulder from Monte Grappa in Italy that was donated by the Italian Veterans of Cleveland. The eighteen-foot ornamental iron gate that presides in front of the Hungarian Garden's main entrance was a wrought-iron copy of a traditional "Szekely Kapus"-a hand-painted and colored wood gate typical of Eastern Hungary from where many of the region's Hungarian immigrants had migrated. By forging the gate in iron, the Hungarian delegation interpreted their past using local vernacular, drawing craftsmen from and connections to Cleveland's thriving steel and iron industries. ${ }^{12}$

Cleveland's artisans, architects, and artists built the Gardens into significant artistic accomplishments, generally interpreting plans designed by local ethnic communities. The Gardens were shaped by some of the nation's leading landscape architects, including James Lister a graduate of Cornell and fellow in the American Academy of Rome, who influenced the Gardens from his position on the City Planning Commission. Likewise, Amos Mazzolini sculpted busts for the Polish Garden before embarking on a long career as an artist at Ohio's Antioch College, where he opened an art foundry. Born in Cleveland to immigrant parents, Frank Jirouch attended the Philadelphia Academy of Fine Arts and exhibited at the 
Figure 3

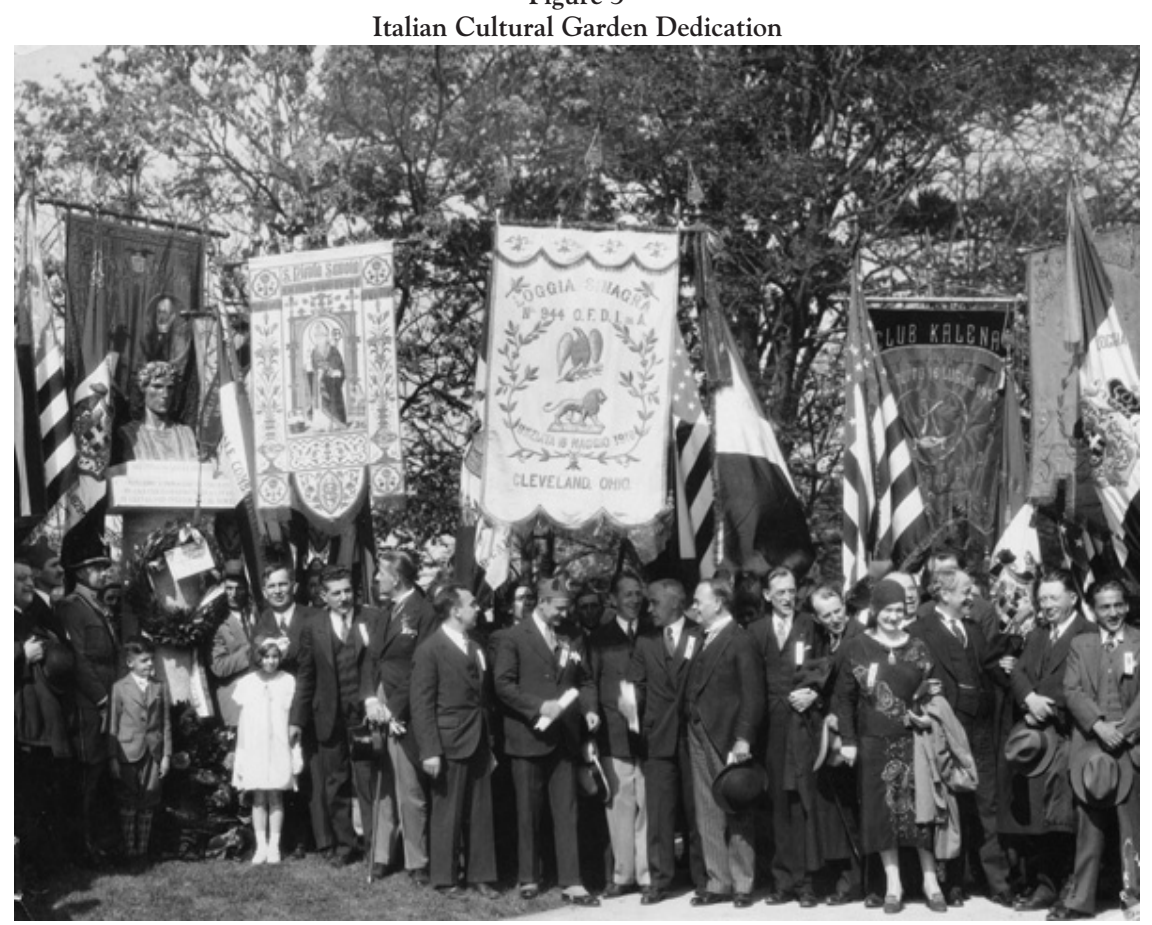

Members of the Italian social and cultural organizations turned out for the dedication of the Italian Cultural Garden. They are seen surrounding the bust of Virgil and a column from the Roman Forum, both gifts of the Italian government and Mussolini. Credit: Cleveland Public Library

Salon Francaise in Paris before returning to Cleveland and sculpting as many as a quarter of the busts in the gardens. Renowned cubist Alexander Archipenko sculpted figurative busts of Ukrainian nationalist poets Taras Shevchenko and Ivan Franko that take a subtly different approach to monumental sculpture than other statues in the Gardens. Interestingly, Archipenko's sculptures only hint at his more radical interpretive works, which suggests the powerful manner in which the tradition of representative sculpture associated with nineteenthcentury centenary commemorations shaped the Gardens. ${ }^{13}$

Most commonly, the Gardens hosted centenary rituals to unveil busts of cultural figures whose music, writing, religion, and/or political activism had come to embody national revival or who were proponents of statehood-circumventing prohibitions against commemorating political or military leaders. Physician and folklorist Jonas Basanavicius was the "patriarch of the Lithuanian national Renaissance" and first President of the Lithuanian Republic. Sociologist Thomas Masaryck shaped Czech national revival through the first half of the twentieth century, and later was elected first president of Czechoslovakia. Jan Kollar was a Lutheran minister whose poetry was most notable for its significance in resisting Magyarization during the Hungarian dominance of Slovakia. The poetry of Petar Njegos, Ivan Cankar, and Taras Shevchenko defined national revival among Serbs, Slovenes, and Ukrainians. ${ }^{14}$ 
The Gardens were influenced by traditions in European landscape design. Italian Renaissance design, popular in the United States in the 1930s, was most commonly used, perhaps because it lent itself well to the sharply sloped topography. Fountains, pools, steps, multi-leveled terraces, and walls appear in several Gardens. Religious designs also shaped many of the gardens. Burton Ashburton Tripp organized the Hebrew Garden around a brick-laid patio shaped into a Star of David, and A. Donald Gray planned the Irish Garden around a Celtic Cross, composed of turf, slate, and sandstone walks, and sedum-filled lunettes. Irish juniper, yew and white lilac, hawthorn, lavender and wisteria were planted; shamrocks, cowslips, and Shannon Roses bordered the cross. Present in nearly every garden, Judeo-Christian traditions are a conspicuous commonality shared by many Gardens, even though ethnic Catholic churches were often points of community conflict. ${ }^{15}$

Curiously, when the CGL carved up the hillsides of Rockefeller Park, it delineated physical boundaries between the respective Gardens, thus emphasizing their distinctiveness as opposed to a broader harmony of design. Of particular note, the CGL did not initially consider connections between Gardens nor did it advocate for common design elements. Although they spent countless hours planning their respective Gardens, for the most part Garden delegations worked independently. They created formal designs with well-delineated exits and entrances centered upon architectural features. This lends each space a formal, almost introspective character, with little or no reference to the surrounding complex of gardens. This aspect of the Cultural Gardens reveals itself most fully when judged from above- by an aerial photograph or on a landscape drawing. This omission was noted and addressed by the City Parks Department whose landscape architect, Harold E. Atkinson, created a "unification plan" in 1937, stating that "more adequate ingress would be required and that a circulatory path system linking the gardens would be provided." Atkinson, however, was not sanguine about creating real unity because the "abundance of masonry" and steep hillsides worked against developing anything more than a "circulatory path."16

If physical unity was difficult to create, harmony among the Gardens' nationality groups also remained an obstacle. Many of the symbolic figures chosen for commemoration in various Gardens represented social and political trends that directly opposed other figures or cultural groups. For example, the Slovaks and Czech celebrated figures that advocated pan-slavism in the face of the Austro-Hungarian Empire, including figures like Jan Kollar and Frantisek Palacky. Meanwhile, Serbians, Slovenians, and Croatian, for example, battled relentlessly over the nature of the Yugoslav garden. Although they shared a space, its heroes in these groups formed three committees to manage the garden, each memorializing separate figures and ceremonies. Moreover, the three groups fought over the individuals to be memorialized in the garden, eliminating a proposed Croatian statue to progressive Catholic Bishop George Strossmayer, for instance. The Slovenian Garden delegation feuded internally over who to honor. And, finally, before the Yugoslav Garden was even constructed, a Slovenian statue was stolen, leading to recriminations between the committees. ${ }^{17}$

To the degree that the Gardens' founders offered a distinctive vision of American identity in the Gardens collectivity, that vision grew muddled and less distinct as the Gardens expanded. For the Gardens' founders, the act of 
Figure 4

Szekely Kapus

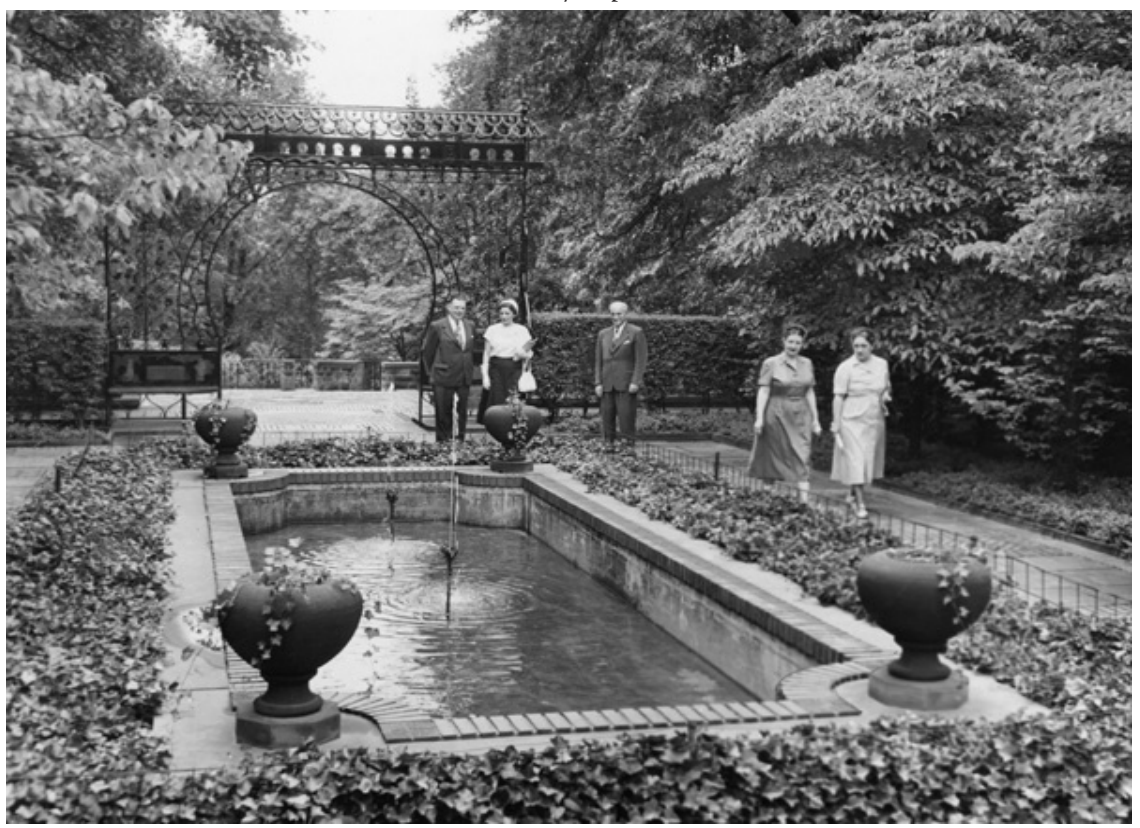

Leaders of the Hungarian Cultural Garden Delegation, Judge Louis Petrash, Miss Lily Volosin, and Judge Julius M. Kovachy, walk through the Hungarian Garden in 1950. In the background is the wrought-iron szekely kapus, a variant on a traditional Hungarian gate, showing how European cultural forms were adapted to the Gardens. Credit: Cleveland Public Library

establishing and building the gardens unquestionably symbolized a commitment to American democratic ideals and citizenship. As the city's "nationality" communities came together, they provided a vision of unity to Cleveland, the nation, and the world. In America, unity and peace were being forged among disparate national ethnic groups; the American nation was thus comprised of multiple traditions and ideals. In this framework, it would seem that there would be no need to build an American garden. But, in 1933, the CGL first invited the Cleveland Council Parent Teachers Associations to adopt a garden. The first of two American Cultural Gardens, oddly named the American Colonial Gardens, focused on patriotic expressions by schoolchildren; it honored satirist Mark Twain in 1935 and United States Secretary of State John Hay in 1939. The presence of American patriotism grew increasingly strident when the Veterans of Foreign Wars sponsored an American Legion Peace Garden, which would eventually develop two distinctive sections, one for "Nations" and one for "States." Having former soldiers involved would seem to conflict directly with the Garden League's emphasis on non-political and non-military figures. However, the Gardens' official historian resolved this contradiction by emphasizing that veterans were "pledged to combat the autocracy of both the classes and the masses, to promote peace and good will on earth and to safeguard and transmit to posterity the principles of justice, freedom and democracy. These concepts are the embodiment of the spirit and purpose of the Nationality Gardens." Nonetheless, the new additions 
complicated the Gardens' message and undermined the Gardens as metaphor for the United States and its constituent parts. ${ }^{18}$

As Clevelanders embedded identity into art and landscape, the Cultural Gardens came to be a complicated and contradictory place that extended cosmopolitanism in the city. Although a collection of disparate elementsarchitectural design, sculpture, craft, and organic materials, the Gardens acquired monumental import through their collective integration and reconciliation of multiple layers of conflicting ideals. They became sacred spaces as they brought together, in Cleveland, diverse expressions of international cultural identity. They balanced conflict-local, national, and international—within the cooperative idiom promoted by the Cultural Gardens league. This lent Cleveland's landscape a different sensibility from other American cities, such as New York, where municipal public art monuments flourished, but did so under the auspices of elite and academic leaders. The "civic ideal" being promulgated in most American cities was not directly connected to the city's diverse communities. Also, generally speaking, most public art projects generally were not conceived in reference to one another or as holistic and unified projects. Thus the Cultural Gardens were able to relocate, at least metaphorically, broader conflicts into a controlled fracas among commemorative statues in Rockefeller Park. The Gardens became sites of negotiation for international identity. They became a place in which Americans explored the boundaries of their ethnic and American national identity and a place in which residents of Cleveland demarcated their communities and defined their city. ${ }^{19}$

By the start of World War II, the eighteen Gardens had become a vibrant part of the city's social fabric. Remarkable numbers of people visited or attended celebrations in the Gardens. For example, over 60,000 Cleveland residents participated in and attended the dedication of the Hungarian Garden on a sunny July morning in 1938, watching as Cleveland's Mayor received the Garden on behalf of the city. The numbers were staggering, in no small part because the census reported that 23,833 people of direct Hungarian descent lived in Cuyahoga County at that time. Just months earlier, on a cold and rainy May morning, a crowd that some estimated to be as high as 100,000 people watched the parade that marked the dedication of the Yugoslav Cultural Garden; another 35,000 attended the opening of the American Legion Peace Garden. Leading cultural and political figures nationally and internationally spoke at the Gardens and ceremonies reached thousands more via radio broadcasts transmitted around the globe. ${ }^{20}$

The Gardens had become shrines with international aspirations and reach as they drew attention from international governments. They had, borrowing from the aspirations of the Slovak Garden League, become centers of "national gatherings and celebrations. Here will be placed the busts of our national leaders and heroes. Here also we intend to plant trees and flowers which are characteristic of our homeland, all as a symbol of our love and pride as Slovaks." We, the delegation reported, "intend to invite and bring our distinguished guests and visitors from Slovakia, for the purpose of planting some tree or shrub as a memento of their visits to this land of freedom and liberty." In 1935, Guillaume Fatio, a representative of the League of Nations, planted an American Elm Tree at the entrance to the Gardens. Planting an American Elm also added ideological depth to the Garden because of the Elm's distinctive place at the center of a 
Figure 5

Aerial View Greek and Lithuanian Gardens

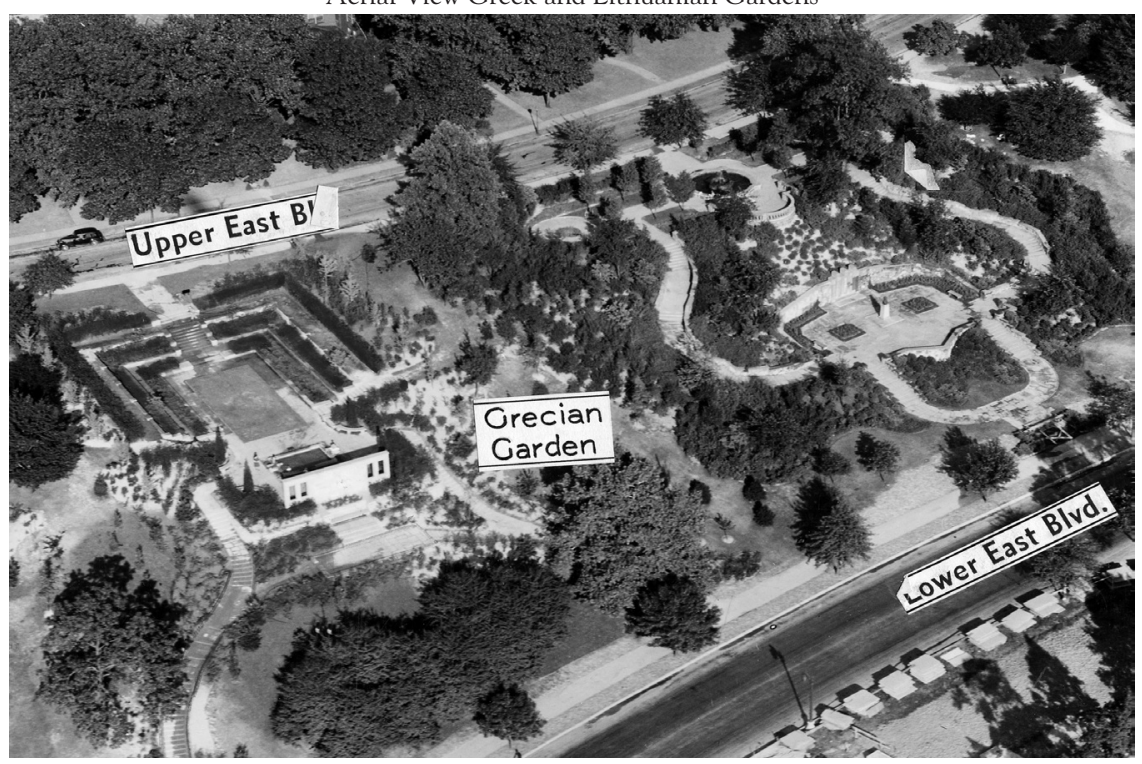

The Cultural Gardens stretch for more than a mile along the steep hillsides of Cleveland's Rockefeller Park, following the path of Martin Luther King Drive (then Lower East Boulevard). Credit: Cleveland Press Collection

mythic American landscape which was developed by environmentalists and literary figures in the $19^{\text {th }}$ century and which was most often associated with the settlement of New England. Elevating the Gardens' stature, Fatio emphasized the uniqueness of the Gardens as a model: "Cleveland's cultural gardens are accomplishing in their community the same thing that the League of Nations is trying to do for the world." He took plans from the Gardens and a record of his visit back to the organization's new Geneva headquarters where, he related, they would be used as a guide for designing the grounds, with 60 garden plots for member nations. Such international interest reveals the Gardens' growing significance in the 1930s. ${ }^{21}$

The integrity of the Gardens, however, was soon tested by war. As tensions mounted in Europe, the distance between the Gardens' mission statement and celebratory activities grew more pronounced. The formal opening ceremony for the completed Garden chain in 1939 featured a political address by an emissary of Roosevelt in support of Britain's battle against the Germans. In addition, representatives of 28 nations stepped up to a monument to "Peace" and, oneby-one, deposited soil, from sacred geographic sites in their home nations and from historic battlefields, into a funnel that emptied into a "Crypt of Nations" at the base of the monument. "There is something terribly real about a handful of soil," wrote Cleveland Plain-Dealer reporter Roelif Loveland. The ceremony made the crypt sacred, employing a technique commonly used to remember war dead, although embodying national identity in physical form called forth ideas that contrasted with the Garden's founding ideology. Intermingled soil in the American Garden suggested an American identity that was more akin to the 
melting pot theory than to Weidenthal's vision of "one out of many." Additionally, the ceremony suggested another vein of thinking that held popular currency at the time: the eugenicist notion that there were organic and biological foundations to identity, which were tied to national origins in a most literal fashion. ${ }^{22}$

Figure 6

Intermingling the Soils

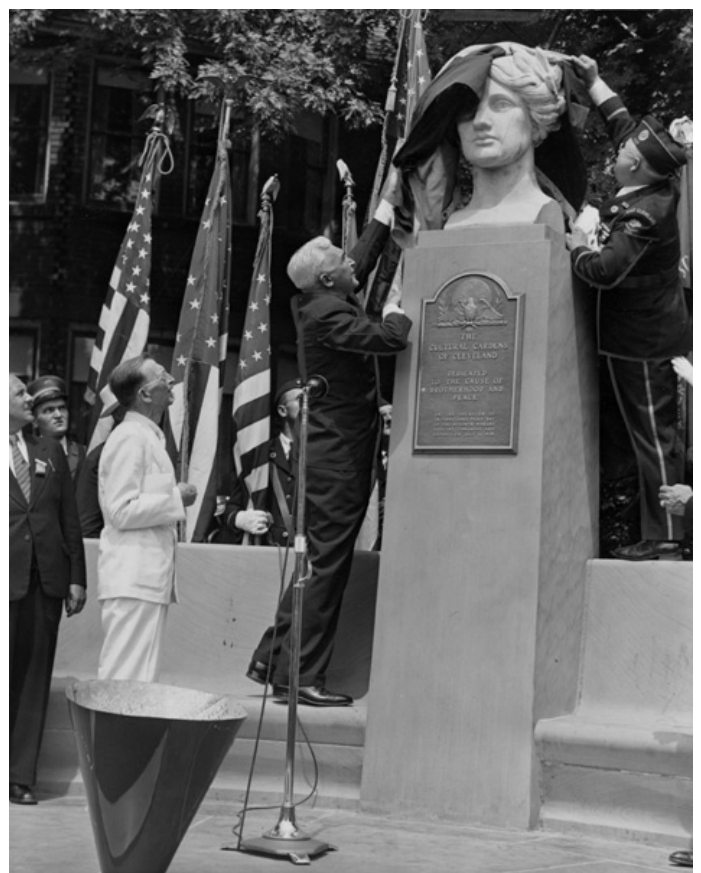

In 1939, representatives of 28 nations deposited soil from their home nations, as well as from European battlefields, into a funnel that emptied into the "Crypt of Nations" at the base of a monument to Peace in the American Garden, sponsored by the American Legion. Credit: Cleveland Public Library

The bombing of Pearl Harbor two years later exacerbated the challenges facing the Gardens. How exactly did one demonstrate ethnic pride and "Americanism" at the same time? The answer quickly became evident as the League passed a resolution to "discontinue all public celebrations and demonstrations on behalf of our respective nationality gardens for the duration of the war." As members of the federation debated what it meant to be "patriotic," they eventually loosened restrictions on holding public events in the gardens but determined that "none but the American flag be displayed on these occasions." Flag pins were distributed at ceremonies and the Gardens held a series of "four freedoms festivals." As patriotism peaked, the Garden League's restrictions on sculpture became lax. In 1940, eighteen months before Pearl Harbor, Charles Wolfram strongly opposed an effort by the City Parks Department to place a statue to Lincoln within Rockefeller Park, contiguous to the Gardens because "inasmuch as it expresses strictly an American Patriotic Historical sentiment with no reference 
to Nationality Groups it does not fit into the theme and sentiment expressed by the Cultural Gardens." Yet not two years later, Wolfram wrote a fellow League delegate, "Our whole-hearted cooperation was pledged to the creation of a "Shrine to George Washington." ${ }^{23}$ American identity was being forged in entirely new ways, which led to a redefinition of the Gardens and their landscapes.

The onset of the Cold War accelerated the transformation of the Gardens into a place where American patriotism drained the Gardens of their distinctive cultural expressiveness and complexity. In 1946, the CGL inaugurated the first festival that involved its entire membership. Held in conjunction with Cleveland's Sesquicentennial, "One World Day" represented a new direction for the organization, one in which ethnic sentiments became explicitly connected to American nationalist sentiments. As happened at festivals and memorials elsewhere in the nation, the Gardens diminished as a place to express difference. Peace, brotherhood, and diversity remained important, but as veneer rather than substance. For example, in 1957, Ohio's Governor (and former Cleveland mayor) Frank Lausche noted that "Americans of other national origins must have a devotion to this country above that to their ancestral heritage. While I love the songs of Slovenia, I love America better." The festival ended that year with American folk dances, a personification of the Statue of Liberty and the audience singing "America." Likewise, Cleveland Mayor Anthony Celebrezze distanced himself from the Gardens as symbols of diversity. To Celebrezze, "The dream of the American melting pot has never been more clearly demonstrated than in the City of Cleveland where the Cultural Gardens stand as a memorial to the diverse nationalities and cultures of our city." Such blind patriotism gradually emptied the Gardens of their uniqueness by diminishing the complexity and diversity of their message. ${ }^{24}$

At the same time the Gardens' social foundation eroded as the city's racial and ethnic composition changed. By the 1950s, immigration restrictions from a generation earlier had begun to alter the ethnic flavor of the city. Cleveland's immigrant community was less than half as large as it had been in 1940. By 1960, only 1 in 10 Clevelanders were foreign born. The white population of the city shrunk by 25 percent as the baby-boom, post-war consumer culture, and racial anxiety drove the children of immigrants to the suburbs, further from the Gardens physically and emotionally. It is precisely at this moment, in the 1950s, that some scholars have argued that suburban children of immigrants became "white," abandoning or suffusing their ethnic heritage in favor a more homogenized identity purchased in shopping malls. Regardless of how completely this change occurred, during the 1970s and 1980s Cleveland's ethnic museumsHungarian Museum, the Ukrainian Museum, and the National Cleveland-Style Polka Hall of Fame-followed their communities (or were pressured to follow them) to the suburbs. ${ }^{25}$

Simultaneously, the city's racial composition shifted as large numbers of black migrants moved North following World War II. In 1940, African Americans already comprised the largest single migrant group to Cleveland, and, by 1960, Cleveland's black population had more than tripled. In the 1940s, census maps showed relatively few black families lived in any of the communities immediately adjacent to the park. To the west, the Hough neighborhood began to change rapidly in the 1940s and 1950s when the movement of a black family into one section of the neighborhood led the "for sale" signs to "sprout likes tulips 
Figure 7

Unveiling Tomas Masaryk Monument in 1961

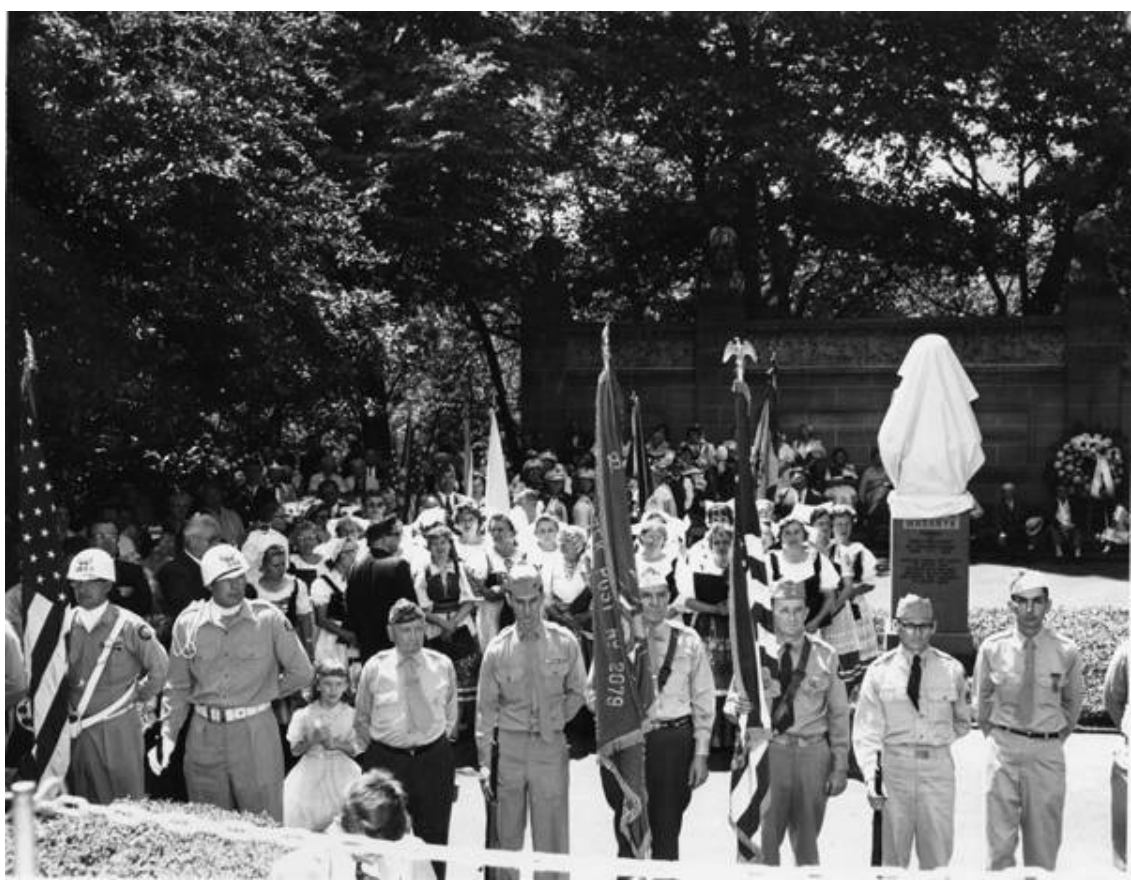

Cleveland's Czech community commemorated the life of the first President of Czechoslovakia in 1961 at the height of the Cold War. In the background is the detailed frieze that depicted the history of the Czech people. Both were sculpted by the renowned architectural sculptor Frank Jirouch, who crafted as many as a quarter of all the Gardens' sculptures. Credit: Cleveland Public Library

in springtime." To the east, in Glenville, the transition occurred more slowly but just as inexorably. An affluent Jewish community in 1940s, Glenville saw its Jewish population plummet in half by 1950, with an increase in the African American population. The last streets affected by this demographic transition were those located directly adjacent to Rockefeller Park. By the early 1960s, the demographic changes to the neighborhood were nearly complete as African Americans comprised over 90 percent of both neighborhoods' population. ${ }^{26}$

Demographic change had a powerful impact on the Gardens because its leadership, like most Americans, had ignored the salience of race when organizing the Gardens and thinking about American cultural identity. To the degree that the Gardens had embodied ethnic complexity, they had avoided altogether confronting the city's multi-racial character. The Gardens had been conceived within the idiom of European immigration. With the exception of a Syrian Garden, which has not yet been built, the Cultural Gardens League did not include immigrant or migrant experiences of any non-European cultural group to the city (or nation). Thus, it is not surprising that as racial inequity emerged as a flashpoint during the post-war years, that the Gardens too would have to confront the legacy of race in America. Beginning in the 1960s, the Cleveland Cultural Gardens Federation (the CCGF being the new name the Cultural Gardens League had given itself in 1952) continued to install new Gardens for 
Finland, Estonia, and Romania, but struggled with the question of how and if to represent the lives of African Americans in the Gardens, a challenge that many of its members were ill-equipped to handle. To the degree that the Gardens had made material the cultural history of Cleveland, the emerging politics of race would compromise their ability to help define the city. ${ }^{27}$

Not long after the Civil Rights struggle gained national attention during the Freedom Summer of 1961, the CCGF briefly considered the merits of creating a "Negro Garden"- the first discussion of race by the organization since its founding. The CCGF dismissed the idea, noting briefly that "An article about the Negro in American appearing in the April $10^{\text {th }}$ issue of LOOK magazine was read in part pointing out to the members present that the American Garden is the place for any bust of American Negro cultural expression. There had been some talk of having a special Negro garden, but as the article in LOOK magazine explains the Negro is American - he does not follow the customs of his so-called 'old country.' America is where his roots are. Nothing official has been presented as yet." A year later, City Councilman Leo Jackson proposed a Negro Cultural Garden, in part as an attempt to stop construction of a high-rise apartment building in Rockefeller Park, but also to give the city's black residents a voice in the Gardens. Not only was the measure killed in committee, but it disappeared from the public conversation for nearly a decade, until well after the election of Carl Stokes as the first black mayor in a major American city. ${ }^{28}$

In the summer of 1966, racial tensions escalated in the Cultural Gardens and the surrounding Hough and Glenville neighborhoods. In June, white supremacists descended on the Gardens and covered park buildings and benches with "anti-Negro slogans, swastikas and KKK symbols." White supremacist graffiti received little media attention and was immediately forgotten against the backdrop of a week of violence during the Hough uprisings of late July 1966. With the summer's tension still smoldering in September, young black power activists defaced or spray-painted phrases "Get Whitey" and "Black Power" on many sculptures, including those of Abraham Lincoln, Baruch Spinoza, and Artemus Ward. Although the young activists were prosecuted for vandalism in the case (and defended by future Congressman Louis Stokes), the incident left a scar on the Gardens. According to Cleveland's NAACP executive secretary George Livingston, the Gardens had become "a battleground between Negro and white youths." Speaking at the $21^{\text {st }}$ Annual One World Day on September 11, 1966, with graffiti stains still clearly evident in the Gardens, Cleveland Plain Dealer publisher and editor Thomas Vail invoked the their symbolic founding principles in the hope that the Gardens could lead the way in healing Cleveland's racial landscape. He urged that "the unity symbolized in the gardens is America's contribution to a world.... We should be reminded that the purpose of all of us must now be directed at curing the evils that have produced racial unrest."29

Bridging the racial divide in the Gardens proved elusive and proceeded slowly. In 1968, Councilman Jackson proposed a memorial to Martin Luther King as the centerpiece of a "Negro Garden," but his proposal went nowhere. However, in 1970, the American Garden dedicated a statue of Booker T. Washington, which was placed in the American Colonial Garden under the auspices of the Tuskegee Alumni Association. Its inscription emphasized Washington's resolve that no man would "degrade my soul by forcing me to hate him." Nonetheless, the monument was out of step with the views of Martin Luther King, Malcolm X, and other black 
Figure 8

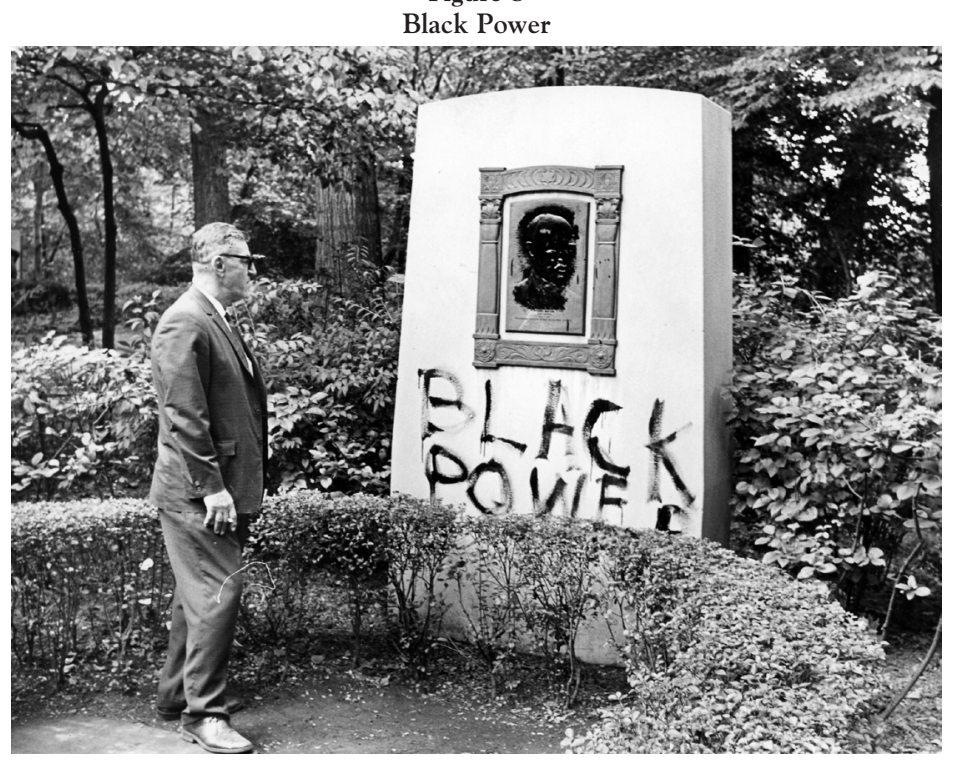

In 1966, in the wake of a KKK rally in Rockefeller Park and the Hough Riots, protesters defaced more than 20 monuments. Credit: Cleveland Press Collection

leaders of the moment. Twice it was "blown up" during the 1970s, in one case the pedestal on which it stood was knocked askew. Despite having received official support of Councilman Jackson, as well as Mayor Carl Stokes, it is perhaps not surprising that the memorial was an insufficient expression of African-American cultural identity. Finally, in 1977, the CCGF granted the land on the west side of Liberty Boulevard for an African American Cultural Garden. In 1981, Liberty Boulevard was renamed Martin Luther King Drive-which helped bridge the racial divide and underscored the CCGF's emphasis on peace and brotherhood. Even so, the African-American Garden remained unfinished, which undermined the core message of the Gardens. In 1983, a Cleveland Plain Dealer reporter editorialized, "the Cultural Gardens, intended to be a monument to an ethnically pluralistic society, have instead become a metaphor for divisiveness and hatred, segregation and racism, unfair housing and the poor relations among people that are at the root of so many urban problems." ${ }^{30}$

Under the weight of the Cold War, demographic change, racial crisis, and a deteriorating economic situation, the Gardens were becoming unmoored from their foundations. The Gardens' symbolism and iconography grew increasingly incomprehensible to Clevelanders not familiar with, or trained in, their cultural origins. The Garden's physical landscape deteriorated. Always an issue, vandalism grew more pronounced in scale and scope. By 1982, for example, more than half of the plaques and monuments were missing from the Park. The City also had removed at least 21 busts from their pedestals to prevent them from being stolen. Litter and graffiti marred the landscape. Maintenance declined alongside city budgets; park staffing was pared by two thirds. Care of the Gardens by city maintenance workers and Cultural Gardens Delegations-trimming of hedges to 
their prescribed heights, pruning, and weeding — diminished, leaving the grounds overgrown, poorly tended, and increasingly out of line with the original plans. According to a report commissioned by the CCGF, and funded by the Cleveland Foundation, it would cost more than $\$ 12$ million to restore Rockefeller Park and over $\$ 250,000$ yearly for maintenance, including lighting, parking, and other amenities. Nobody was certain where such money could be found, but all agreed that the Gardens could one day become a "regional attraction," forgetting the time just forty years earlier when they had attracted international attention. Strategies for renewal no longer focused on highlighting the importance of the Gardens as significant works of art, but centered merely upon restoring Rockefeller Park's landscape. ${ }^{31}$

Despite public calls for renewal the CCGF also began to view the Gardens as lost. In 1981, the CCGF considered moving the Gardens downtown, an idea that the group broached with the mayor. Although this idea met with little enthusiasm, the CCGF again contemplated abandoning Rockefeller Park in 1988. It proposed construction of a "Hall of Nations" adjacent to the nearby Rockefeller Park Greenhouse, with "24 sections, one for each garden. Put statues under lock and key, but open to the public daily. A showcase of busts now in storage." CCGF delegates traveled to Milwaukee, Pittsburgh, and Salt Lake City to explore nationality exhibitions in those cities. The plan never went beyond a preliminary architectural sketch, but the CCGF became increasingly desperate. Rockefeller Park appeared to be beyond repair and the Gardens had lost much of their cultural resonance. With the physical infrastructure disappearing, the prospect of recovery appeared dim. The CCGF considered the unthinkableseparating the sculpture from the Garden landscape to which they were connected - abandoning the Gardens as a living entity and creating a traditional museum with the remaining sculpture. ${ }^{32}$

Even as the Gardens foundered, the seeds for possible rebirth were being planted among new immigrant communities, which viewed the Gardens as a landscape into which they could make a claim about their community's vibrancy. In 1981, when a delegation from Cleveland's sister city, Taipei, visited Cleveland, it suggested that Taipei "should present and build a Chinese Cultural Garden in Rockefeller Park as a gift." Although there was only a very small Chinese community in Cleveland, the Garden was funded by Taipei's people and its business community to the tune of $\$ 500,000$. Conceived as a political statement about Taiwan's claim to be the true China, the Garden included the National Flower of the Republic of China (Taiwan) and the flower of Taipei, as well as a bust of Confucius. Constructed in Taiwan and shipped to Cleveland in 1984, the Chinese Garden went into limbo, crated in a municipal garage, as a battle about the Garden's location erupted. The problem began when the City and the Chinese Association of Greater Cleveland had misgivings about the site. The Chinese Garden Delegation, led by local business leaders Alex Mark and Anthony Yen, expressed concern that the Garden would not be very visible and that they would have to build a bridge across Doan Brook to allow access to the Garden. The city, meanwhile, was concerned about vandalism and security in Rockefeller Park. Both sought to move the Gardens into Wade Park, in the heart of the University Circle Cultural District. This change was approved by the City Council but vetoed on procedural grounds by the Mayor, George Voinovich. The Cultural Gardens Federation supported the Mayor's veto, preferring that the 
Chinese Garden be located in the chain of gardens, on the west side of Liberty Boulevard, adjacent to the Finnish Garden, not one mile from the main chain of Gardens. In a letter to the CCGF, Mark urged the organization to reconsider its support of the mayor's veto because the Chinese Garden would be the first addition in many years, and "the Chinese Gardens will help bring more visitors and tourists to visit all the Cultural Gardens in the area." Even more to the point, Mark argued that "this in turn will focus more public attention to the gardens for increased public support and may attract more ethnic communities to build gardens in the area rather than moving away or locating to the suburbs." Put another way, Mark believed that art could remake place in Cleveland. ${ }^{33}$

Perhaps more critically, the abrupt ending of the Cold War generated renewed conversation about the Gardens as a place where communal and national identity could be negotiated and articulated. The cessation of the Cold War freed the Cultural Gardens from the heavy weight of American patriotism, which had become a rhetorical prison. It also allowed pent-up frustrations to surface. Conflict between Serbs and Slovenes over the Yugoslav Garden emerged in 1990, as international tension heightened in the Balkans with the disintegration of Yugoslavia. The Slovenian Delegation requested that Garden be renamed the Slovenian Garden. The Serb Delegation agreed, after much cajoling. Even before the breakup of Yugoslavia, however, it appears that the Serbian delegation had already abandoned the Cultural Gardens, removing its contribution to the Yugoslav Garden to the suburbs. The bust of poet Petar Petrovich Njegosh became the centerpiece of an alternative commemorative site on the grounds of St. Sava's Serbian Orthodox Church, where the Serbian community would also celebrate an orthodox priest who fought against the Nazis during World War II. Even so, by the millennium, the Serbian Delegation was planning its return to the Cultural Gardens. ${ }^{34}$

The end of the Cold War set off a new wave, albeit small, of immigration to Cleveland, including a number of Ukrainians. Predominantly orthodox Christians who settled in Cleveland's suburbs where the Ukrainian community had relocated itself and its churches, these immigrants helped fuel the rebirth of the Gardens. One particular migrant, Lena Pogrebinsky, drove by the Gardens and was horrified at the condition of the Ukrainian Garden. She lent energy and enthusiasm to the task of saving the Gardens. She helped to locate several missing statues-presumed stolen for many years - that had been removed for safekeeping and were stored in a city garage, covered with oil under a tarpaulin. Emblematic of the efforts of new immigrants and old immigrants alike, Pogrebinsky's activism revealed the grassroots revitalization that had begun to take place in the Gardens during the 1990s. Revitalization efforts were joined by demands for new gardens as well. Immigrants from India, who had began to move to Cleveland in small numbers in the 1960s, had built a vibrant community and were seeking to leave a mark on their new homeland, much as Europeans had done two generations earlier. Efforts to create an India Garden first appeared in 1979, but creating an India Cultural Garden gained steam in the mid-1990s. Likewise, other cultural groups within the city, including Latvians and Armenians, also sought a place in the Gardens. They were joined by a delegation from Azerbaijan, whose President wanted to express the country's newly formed national identity. Coupled with significant investment from local foundations, the construction of new Gardens represented a dramatic turnaround. ${ }^{35}$ 
As the Gardens have once again blossomed, challenges remain. Maintenance of the park infrastructure, especially aging fountains and deteriorating stonework, poses significant financial hurdles. Additionally, the park's landscape has been neglected and poorly looked after for many years, leaving lingering problems with overgrown trees, root damage, and poorly trimmed hedges. Vandalism and theftof statues and even annual plantings - continue to be problematic, especially in a city with exceptional poverty rates. Restoration work is of uneven quality. Lingering concerns from the 1970s, about parking, lighting, and access, have been addressed incompletely. Finally, although the Cultural Garden Federation has embraced the African-American community, the incomplete AfricanAmerican Garden reflects just how intractable of an obstacle race continues to be in America, especially in old, formerly industrial, cities like Cleveland. Indeed, today, both weeds and new growth and empty pedestals and new statues continue to exists side-by-side in the Cultural Gardens, offering a tantalizing vision of the possibility against a sobering backdrop.

Recent events in the Cultural Gardens reveal the broader struggle going on in America's older cities, one that seeks to remake rather than abandon them. Using the Gardens as a stage, many of Cleveland's newest citizens are imprinting their communal identity into the city's symbolic landscape. In so doing, they have contributed to the rebirth of the Cultural Gardens, but it is not clear that the Gardens will reacquire the significance that they once held. The Gardens stood as a singular work of landscape architecture that offered a vision of unity to a nation and a world torn by war, economic depression, and xenophobia. And, yet, they have both defined and been bound inextricably to the fortunes of Cleveland, as a place. As Cleveland's fortunes changed, so too have those of the Gardens. Demographic, economic, and political currents reshaped the physical and symbolic contours of the Gardens. Cultural conflict eroded the intensity of the Gardens' founding metaphor of peace and brotherhood; economic changes imperiled their physical structure. The intersection of both trends forced the Gardens into dormancy by the 1970s. The emergence of multiculturalism and the end of the Cold War, along with broader attempts to recover Cleveland, have helped to generate new growth in the Gardens. Whether the Gardens will continue to flourish, however, remains an open question. It will depend on whether recovery efforts retain both the integrity of the Gardens as symbolic places and as works of public art-tending not merely to the landscape and architectural elements but also to their cultural legacy.

Department of History

Cleveland, $\mathrm{OH} 44115$

\section{ENDNOTES}

1. Phillip Morris, "Cultural Harvest Dying on the Vine," Cleveland Plain-Dealer, July 5, 2007; Robert L. Smith, "Cultural Gardens Reviving, Cleveland Plain-Dealer, August 29, 2006; Robert L. Smith, "Garden chain adding link for first time in 21 Years," Cleveland Plain-Dealer, September 24, 2006. This essay made extensive use of the Cleveland Plain-Dealer Newspaper Morgue; the papers of the Cultural Gardens Federation (formerly the Cultural Gardens League) are housed at the Western Reserve Historical Society, Manuscript Collection 3700. On the Cultural Gardens, see Clara Lederer, Their Paths Are Peace (Cleveland, 1954); also, this essay has a debt to John Bodnar's discussion of the 
Cultural Gardens, even when my conclusions differ in emphasis; John Bodnar, Remaking America: Public Memory, Commemoration, and Patriotism in the Twentieth Century (Princeton, 1992), 97-104.

2. For an excellent introduction to the history of gardens, see John Dixon Hunt, "Come into the Garden, Maud": Garden Art as a Privileged Mode of Commemoration and Identity," in Joachim Wolschke-Bulmahn, editor, Places of Commemoration: Search for Identity and Landscape Design (Washington, DC, 2001), 20-21; On the invention of tradition, and commemorative activity, see Eric Hobsbawm and Terrence Ranger, The Invention of Tradition (New York, 1992); John R. Gillis, editor, Commemorations: The Politics of National Identity (Princeton, 1994).

3. For an excellent overview of the scholarly literature in the study of memory and monuments, see Kirk Savage's online essay for the National Park Service's research division, Kirk Savage, "History, Memory, and Monuments: An Overview of the Scholarly Literature on Commemoration," http:// www.nps.gov/history/history/resedu/savage.htm (June 1, 2007); There is an expansive literature on public arts and historical approaches to them; for examples of the various types, see: Michele $\mathrm{H}$. Bogart's essay "The Ordinary Hero Monument in Greater New York: Samuel J. Tilden's Memorial and the Politics of Place," Journal of Urban History Volume 28, No. 3 (2002), 267-299; Michele H. Bogart, The Politics of Urban Beauty: New York and Its Art Commission (Chicago, 2006); Kirk Savage, Standing Soldiers, Kneeling Slaves: Race, War, and Monument in Nineteenth-Century America (1997); Edward T. Linenthal, Sacred Ground: Americans and their Battlefields (1991); Martha Norkunas, Monuments and Memory: History and Representation in Lowell, Massachusetts (Washington, DC, 2002); Melissa Dabakis, Monuments Of Manliness : Visualizing Labor In American Sculpture, 1880-1935 (Washington, DC, 1998); Terence Young, Building San Francisco's Parks, 1850-1930 (Baltimore, 2004); James E. Young, The Texture of Memory: Holocaust Memorials and Meaning (New Haven, 1993).

4. Musil quoted in Kirk Savage, "The Life of Memorials," Harvard Design Magazine Number 9 (1999): 1; for the full context, Robert Musil, Posthumous Papers of a Living Author, trans. Peter Wortsman (Hygiene, Co., 1987). Mumford agrees with Musil that collections of stone, architectural ornament, and statuary lent the Gardens an aura of permanence so often connected to modern monuments, giving them, according to critic Lewis Mumford, "a false sense of continuity and a deceptive assurance of life." See Lewis Mumford, The Culture of Cities (New York, 1938), 434.

5. For an overview of the history of Doan Brook, see Laura Gooch, The Doan Brook Handbook (Cleveland, Oh.: Shaker Lakes Nature Center, 2001); on Olmstead and rural cemeteries, see for example, David Schuyler, The New Urban Landscape: The Redefinition of City Form in NineteenthCentury America (Baltimore, 1988), 37-56; on the City Beautiful movement and Progressive Era planning, see for example, Jon A. Peterson, The Birth of City Planning in the United States, 1840-1917 (Baltimore, 2003); on parks and park planning, see Roy Rosenzweig and Elizabeth Blackmar, The Park and the People: A History of Central Park (Ithaca, 1998); Galen Cranz, The Politics of Park Design: A History of Urban Parks in America (Cambridge, 1982); Young, Building San Francisco's Parks, 18501930 (2004); on Burnham in Cleveland, see Kenneth Kolson, Big Plans: The Allure and Folly of Urban Design (Baltimore, 2001), 49-64.

6. For gardeners' appropriation of Shakespeare, see Henry Nicholson Ellacombe, The Plant-Lore $\mathcal{E}$ Garden-Craft of Shakespeare (London, 1884); Walt Crane, Flowers from Shakespeare's Gardens (London: Cassell, 1906). On Weidenthal's goals, see Leo Weidenthal, From Dis's Waggon: A Sentimental Survey of a Poet's Corner; The Shakespeare Garden in Cleveland (Cleveland, 1926); Lederer, 39-43; F. Leslie Speir, Cleveland: Our Community and Its Government (Cleveland, 1941), 107-108; Cleveland's commemoration feature the creation of a formal garden that became a living embodiment of Shakespeare's central place in Western Civilization. In an elaborate opening ceremony, Weidenthal unveiled a sculpture of Shakespeare. He invited film icon Ethel Barrymore, Shakespearean actress Julia Marlowe, and other notables, to plant Hawthorne, Elm, and English Oak trees, as well as flowers in the Victorian tradition of planting gardens using flora mentioned in Shakespeare's writings. On other Shakespeare celebrations, see Werner Habicht, "Shakespeare Celebrations in Times of War," Shakespeare Quarterly (2001), 441-455; Copellia Kahn, "Remembering Shakespeare Imperially: The 1916 Tercentenary," Shakespeare Quarterly (2001), 456-478. Ronald Quinault, "The Cult of the Centenary, 1784-1914," Historical Research Vol. 71, No. 176 (1998), 303-323; Percival Chubb, "What the Shakespeare Tercentenary Celebration Might Mean for the Schools," The English Journal Vol. 5, No. 4 (1916): 237. 
7. On Cleveland, see David Hammack, et. al., editors, Identity, Conflict, $\mathcal{E}$ Cooperation: Central Europeans in Cleveland, 1850-1930 (Cleveland, 1999), 12-44; Robert Wheeler and Carol Poh Miller, Cleveland: The History of a City (Bloomington, 1995), 156-182; Campbell J. Gibson and Emily Lennon, "Historical Census Statistics on the Foreign-born Population of the United States: 18501990," Population Division Working Paper, Number 29, United States Bureau of Census (1999), $<$ http://www.census.gov/population/www/documentation/twps0029/twps0029.html> (October 17, 2008); on the Mayor's unity commission, I am indebted to discussion with John Grabowski, editor of the Encyclopedia of Cleveland History; on the involvement of ethnic elites see Bodnar, Remaking America, 94-109; for quotes on organizational goals, see Articles of Incorporation, ca. 1926, Folder 1, Container 1, Cleveland Cultural Gardens Collection, Manuscript Collection 3700, Western Reserve Historical Society; hereafter cited as CCG Collection.

8. Wiedenthal quote from Lederer, 9, 19-20; "Whatever Became of the Cultural Gardens?," Cleveland Plain-Dealer, January 16, 1978; untitled, Cleveland Plain-Dealer, October 11, 1942; untitled, Cleveland Plain-Dealer, July 11, 1951. Newspaper citations come from multiple sources: my own search, The Cleveland Press Collection, the Western Reserve Historical Society, Cleveland Cultural Gardens Collection, and the Cleveland Plain-Dealer Newspaper Morgue. Articles cited as "untitled" are taken from clippings in the Cleveland Plain-Dealer Newspaper Morgue; Israel Zangwill, The Melting Pot: A Drama in Four Acts (New York, 1909); on the National Origins Act, see David J. Goldberg, Discontented America: The United States in the 1920s (Baltimore, 1999), 140-167; for a discussion of Zangwill and Shakespeare, see Copellia Kahn, "Remembering Shakespeare Imperially: The 1916 Tercentenary," Shakespeare Quarterly, 456-478; for quote from Slovak Delegation, Scrapbook, Slovak Garden, Folder 2, Container 6, CCG Collection.

9. On the rules of the organization, see for example, Cleveland Cultural Gardens-Authorization Ordinances, Folder 1, Articles of Incorporation, Container 1, CCG Collection; Constitution of the Cultural Gardens Federation, January 4, 1952, Folder 2, Constitutions, 1952, 1960, 1967, undated, Container 1, CCG; On oversight and interactions between the Gardens and the City Parks Department, see for example, December 7, 1938, "Letter from H. E. Varga to F. E. Bubna, Executive Assistant in Charge of Federal Relations," Folder 8, Correspondence, 1929-1938, Container 1, CCG Collection; The American Colonial Garden Plan, August 17, 1937, Folder 1, The American Colonial Gardens, Container 4, CCG Collection; "Memorandum to the City Plan Commission Regarding Plans for the Jugoslav Garden," March 24, 1933, Folder 8, Correspondence, 1929-1938, Container 1, CCG Collection; A Perspective of the Proposed Plan, The Slovak Cultural Garden, n.d., Oversize Folder, CCG Collection; The Preliminary Plan, The Slovak Cultural Garden, n.d.,, Oversize Folder, CCG Collection. See note below for documentation of WPA funding.

10. The City Record, September 3, 1930; The City Record, May 9, 1927, Cleveland Cultural GardensAuthorization Ordinances, Folder 1, Articles of Incorporation, Container 1, CCG Collection; Speir, 108; Lederer, 22; "Hungarian Garden Drive Starts Today," Cleveland Plain-Dealer, May 17, 1939; "Two Gardens Will Bloom Under Grants from the WPA," Cleveland Plain-Dealer, April 3, 1939; for discussions of Garden fundraising and planning efforts see Cultural Gardens League minutes dated, October 9, 1936, September 14, 1937, April 8, 1938, July 11, 1938, July 16, 1938, July 6, 1938, January 23, 1939; March 17, 1936, April 23, 1936, September 12, 1941, Folder 3, Minutes, 1932 1952, Container 1, CCG Collection; April 27, 1950, Folder 4, Minutes, 1949-1963, Container 1, CCG Collection. Clara Lederer estimates a total of $\$ 1,250,000$ was spent prior to 1954 (page 22). I calculated the $\$ 650,000$ number from reading the Cultural Garden League minutes, especially Folder 3, Minutes, 1932-1952, Container 1, CCG Collection, and comparing it to federal records, which typically cover the period after 1937. See NARA, WPA State Records, Ohio Projects: Slovenian, 6542-1952; Polish, 65-42-492; Greek, 165-42-3099; Czech, 165-42-3111 and 65-42-17175; Hungarian, 165-42-17156 and 165-42-3175; Jugoslav, 65-42-6594 and 65-42-3038; Hebrew, 65-42-3088; Lithuanian, 65-42-2255; Slovak, 165-42-3207; multiple garden projects joined by the City Parks Department, superseding earlier requests, 165-42-3207 and 465-42-2-109.

11. Lederer, 55-61; Speir, 107ff; untitled, Cleveland Plain-Dealer, October 11, 1942, July 11, 1951; on Rabbi Abba Hillel Silver see Marc Lee Raphael, Abba Hillel Silver: A Profile in American Judaism (New York, 1989); Mark A. Raider, Jonathan D. Sarna, and Ronald W. Zweig, editors, Abba Hillel Silver and American Zionism (New York, 1997). 
12. John Mihal, "Flow of Roman Culture Will Theme Garden," Cleveland Plain-Dealer, September 15, 1937; Lederer, 61-67; "Arts of Hungary," Cleveland Plain-Dealer, July 1, 1938; "Garden is Dedicated to City's Hungarians," Cleveland Plain-Dealer, 1938.

13. On Cleveland arts and artists, see for example, William H. Robinson, editor, Transformations in Cleveland Art, 1796-1946: Community and Diversity in Early Modern America (Cleveland, 1996). Artists who worked in the gardens, such as sculptor Max Kalish, also engaged the city's burgeoning and renowned fine arts community by participating regularly in the Cleveland Museum of Art's influential May Show, which from its inception in 1919 served as a vehicle to prominence for artists nationwide. On Jirouch, Kalish, and Lister, see Encyclopedia of Cleveland History entries: Jirouch: http:/ech.case.edu/ech-cgi/article.pl?id=JFL; Kalish: http://ech.case.edu/ech-cgi/article.pl?id=KM1; Lister: http:// ech.case.edu/ech-cgi/article.pl?id=LJM1; (January 9, 2007); Lederer, 83-86.

14. For a description of these statues and their significance, I triangulated newspapers references with scholarship. See, for example, Lederer, entire, Speir, 106-113; Alfred Erich Senn, Lithuania Awakening (Berkeley, 1990), 35; Mikulas Teich, "Review: The Meaning of History: Czechs and Slovaks," The Historical Journal, Vol. 39, No. 2 (June 1996), 553-562; Davic Aberbach, "The Poetry of Nationalism," Nations and Nationalism, Volume 9, number 2 (2003), 255-275; Andrew B. Wachtel, "How to Use a Classic: Petar Petrovich Njegos in the Twentieth Century," in John Lampe and Mark Mazower, editors, Ideologies $\mathfrak{E}$ National Identities: The Case of the Twentieth Century Southeastern Europe (New York, 2004), 131-154. For the broader context see, Hobsbawm and Ranger, The Invention of Tradition (1992); Gillis, Commemorations (1994).

15. On the prevalence of New Deal design in New Deal art and in the Gardens, see Phoebe Cutler, The Public Landscape of the New Deal (New Haven, 1985), 29-30; for a historical primer on landscape design, more broadly, see Elizabeth Barlow Rogers, Landscape Design: A Cultural and Architectural History (New York, 2001); for a description of each Garden design and its elements, see Lederer, entire; Speir, 114-116.

16. For an aerial view of the Gardens see for example, Aerial View, Cultural Gardens, Cultural115, Cleveland Press Collection, <http://images.ulib.csuohio.edu/cdm4/item_viewer.php?CISOROOT=/ press\&CISOPTR $=1202>$ (July 7, 2009); to get a sense of Garden layout and design, see Map, Italian Garden, Cultural015, Cleveland Press Collection, <http://images.ulib.csuohio.edu/cdm4/ item_viewer.php?CISOROOT=/press\&CISOPTR $=1131>($ July 8, 2009); for a sense of the Gardens' spatial arrangement more broadly see the author's digital history project, $<$ http://www.culturalgardens. org/> (January 1, 2008). Atkinson quote taken from "Unification Plan for the Cultural Gardens," A Radio Talk given over WGAR January 30, 1937, Harold E. Atkinson, Folder 8, Correspondence, 1929-1938, Container 1, CCG Collection. See also, Unification Plan for Cultural Gardens, Jos. S. Kreinberg, excerpts from City Plan Minutes of January 5, 1937, Folder 8, Correspondence, 1929-1938, Container 1, CCG Collection; Harold E. Atkinson, typescript, The Cultural Gardens of Cleveland, 1937, Folder 8, Correspondence, 1929-1938, Container 1, CCG Collection.

17. David Hammack, 64, 331-332; "Pan Slavian Theme Rules in Gardens," Cleveland Plain-Dealer, September 16, 1937; May 16, 1938, Folder 3, Minutes, 1932-1952, Container 1, CCG Collection.

18. Lederer, 31-39; "Just Plain Soil Welds People of 28 Nations," Cleveland Plain-Dealer July 31, 1939; also see Bodnar, Remaking America (1992), 103-104.

19. On the civic ideal, see Bogart, Public Sculpture (1997), esp. 1-8, 12-13; Bogart, Urban Beauty (2006), esp. 92-157; more broadly, to view public sculpture in American cities, see for example, Penny Balkin Balch, Public Art in Philadelphia (Philadelphia, 1992); Ira Bach and Mary Gray, A Guide to Chicago's Public Sculpture (Chicago, 1983); Meredith Arms Bzdak and Douglas Petersen, editors, Public Sculpture in New Jersey: Monuments to Collective Identity (Camden, 1999).

20. Cuyahoga County census data for 1940 from Historical Census Browser, University of Virginia, Geospatial and Statistical Data Center (2004) <http://fisher.lib.virginia.edu/collections/ stats/histcensus/index.html> (June 11, 2007); on the dedications, see Norbert Yassanye, "Garden Dedicated by Yugoslav Group," Cleveland Plain-Dealer, May 16, 1938; James D. Hartshorne, "CoOp Effort Called Way to Avoid War: Speech at Gardens Viewed as Bid for Presidential Support for Campaign," Cleveland Plain-Dealer, July 31, 1939; "Ten-Year Dream Comes True As Irish Dedicate 
Garden Plot," Cleveland Plain-Dealer, October 30, 1939; Margaret Suhr Reed, "26 Nationalities Celebrate Cultural Gardens' Birthday," Cleveland Plain-Dealer, May 6, 1951; for radio broadcasts, see untitled, Cleveland Plain-Dealer, July 6, 1938.

21. On the aspirations of the Slovak Delegation, see Scrapbook, Slovak Garden, Folder 2, Container 6, CCG Collection; on the American Elm, see Thomas J. Campanella, Republic of Shade: New England and the American Elm (New Haven, Ct.: Yale University Press, 2003), esp. 2-8; on Fatio and the League of Nations, see "League Emissary Plants Tree Here," Cleveland Plain-Dealer, April 3, 1935; "Cultural Gardens Draw League Eye," Cleveland Plain-Dealer, April 7, 1935; "Tour Cleveland's Famous Cultural Gardens," Cleveland Plain-Dealer, July 2, 1935.

22. "Just Plain Soil Welds People of 28 Nations," unidentified newspaper, July 31, 1939, Cleveland Plain Dealer Newspaper Morgue. The crypt was opened once again a decade later, in honor of the creation of the state of Israel, soil from the grave of Zionist leader Theodore Herzl (brought from Israel by Judge Drueher) was added to the soil in the crypt; on this see October 21, 1949, Folder 3, Minutes, 1932-1952, Container 1, CCG Collection; James D. Hartshorne, "Co-Op Effort Called Way to Avoid War: Speech at Gardens Viewed as Bid for Presidential Support for Campaign," Cleveland Plain-Dealer, July 31, 1939.

23. Letter from Charles Wolfram to Samuel Newman, May 6, 1940, Folder 9, Correspondence, 1939 1948, Container 1, CCG Collection; Letter from Charles Wolfram to member of the Cultural Garden League, March 21, 1942, Folder 9, Correspondence, 1939-1948, Container 1, CCG Collection; December 1941, March 24, 1944, Folder 3, Minutes, 1932-1952, Container 1, CCG Collection; July 31, 1939; "Marine General To Unveil Statue: Bust of Washington To Be Dedicated in Garden," Cleveland Plain-Dealer, June 30, 1943;

24. On the inaugural One World Day, July 1946, Folder 3, Minutes, 1932-1952, Container 1, CCG Collection; quote from Lausche from untitled article, Cleveland Plain-Dealer, August 4, 1952; Celebreeze quote from Lederer, 17; Celebreeze spoke regularly, for example, "Fusion of Six Cultures Hails One World Day," Cleveland Plain-Dealer, 1957. On the connection between the Gardens and other commemorations in the United States see Bodnar, Remaking America (1992), especially 41-109.

25. For an overview of the literature on whiteness, see Todd M. Michney, "Root of It All," Reviews in American History Volume 35, Number 2 (2007), 307-314; also see Matthew Frye Jacobson, Roots Too: White Ethnic Revival in Post-Civil Rights America (Cambridge: Harvard University Press, 2006); David Roediger, Working Toward Whiteness: How America's Immigrants Became White: The Strange Journey from Ellis Island to the Suburbs (New York: Basic Books, 2006); the observation about pressures to move the Ukrainian Museum to Tremont came from a conversation with and Andrew Fedynsky, Director of the Ukrainian Museum in Cleveland; Janet Tebben, "Cleveland House Holds Copies of Ukraine Artifacts, Cleveland Plain-Dealer, <http://www.cleveland.com/heritage/index.ssf?/ heritage/more/ukraine/ukraine1.html> (January 1, 2008); an interview with Andrew Fedynsky can be found online: <http://www.archive.org/details/AndyFedynskyInterview> (January 31, 2009); on the Hungarian Museum, see <http://www.jcu.edu/language/hunghemu/> (March 3, 2008); on the Cleveland-Style Polka Hall of Fame <http://www.clevelandstyle.com/>(November 13, 2007); the pressure to move the Gardens to the suburbs is noted in Madeline Drexler, "Pride and Prejudice," Cleveland Plain-Dealer, August 11, 1985.

26. Oral history interview with Jake Rosenheim by Patrick Miller, December 6, 2005, Interview 400019, Cleveland Regional Oral History Collection, Department of History Cleveland State University; for information on changes in the Hough and Glenville neighborhoods, see Todd Michael Michney, Changing Neighborhoods: Race and Upward Mobility in Southeast Cleveland, 19301980 (Ph.D. Dissertation, University of Minnesota, 2004); Howard Whipple Green, Census Facts and Trends by Tracts, Special 1954 Report (Cleveland: Real Property Inventory of Metropolitan Cleveland, 1954); Howard Whipple Green, Population, Family, and Housing Data by Blocks, Cuyahoga County, Special 1941 Report, Real Property Inventory of Metropolitan Cleveland (Volume 1, 1941), 284-286; Howard Whipple Green, Population, Family, and Housing Data by Blocks, Cuyahoga County, Special 1941 Report, Real Property Inventory of Metropolitan Cleveland (Volume 2, 1941), 168-169, 174-175; William A. Behnke Associates, Rockefeller Park: The Future of Rockefeller Park-A Positive Statement (1981), 9. 
27. Constitution of the Cultural Gardens Federation, January 4, 1952, Folder 2, Constitutions, 1952, 1960, 1967, undated, Container 1, CCG; "Ceremony Marks Completion of Finnish Garden," Cleveland Plain-Dealer, August 24, 1964; "City to Get Monument to Estonia," Cleveland Plain-Dealer, June 19, 1966; "Dedication Planned for Enescu Statue," Cleveland Plain-Dealer, October 30, 1969.

28. May 31, 1962, October 26, 1963, Folder 4, Minutes, 1949-1963, Container 1, CCG Collection; "Council OK's Garden Plan of Jackson," Cleveland Plain-Dealer, December 12, 1961; "New Glenville Apartment Project Likely to Stir Fight," Cleveland Plain-Dealer, April 7, 1961; "Negro Culture Garden Blocked," Cleveland Plain-Dealer, June 26, 1962; see Ernest Dunbar, "The Negro in America Today," April 10, 1962, Look Magazine; on Stokes, see Leonard N. Moore, Carl Stokes and the Rise of Black Political Power (Champagne, Il.: University of Illinois Press, 2002); on the Hough riots see, Todd M. Michney, "Race, Violence, and Urban Territoriality: Cleveland's Little Italy and the 1966 Hough Uprising," Journal of Urban History Vol. 31, No. 1 (2006), 404-428.

29. "Undivided World Grows in Gardens, Says Vail," Cleveland Plain-Dealer, September 12, 1966. Vandalism was common in the Gardens, see for example, "Victor Herbert Bust is Stolen by Vandals," Cleveland Plain-Dealer, January 28, 1965; on the 1966 incident, see "Cultural Gardens Vandals Hit," Cleveland Plain-Dealer, September 9, 1966; "Boy Admits Guilt in Park Destruction," Cleveland PlainDealer, December 30, 1966; "Jones Led Gang Vandal Jury Told," Cleveland Plain-Dealer, January 11, 1968; for an image of vandalism, see Cleveland Memory, Cleveland Press Collection, Cultural Gardens, Image Cultural109, online <http://images.ulib.csuohio.edu/cdm4/item_viewer.php?CISOROOT=/pr ess\&CISOPTR=1198\&CISOBOX=1\&REC=1> (March 30, 2009).

30. "Jackson Wants Negroes to Build King Memorial," Cleveland Plain-Dealer, April 16, 1969; "Fifth Dimension Sings to Help Honor Negor," Cleveland Plain-Dealer, May 10, 1969; untitled photograph, Cleveland Plain-Dealer, September 15, 1970; Vivian Witt, "What Future for the Cultural Gardens," Cleveland Plain-Dealer, October 15, 1971; "African Envoys Dedicate Garden for Black Culture," Cleveland Plain-Dealer, October 24, 1977; "Cultural Gardens Reflect City's Illnesses," Cleveland PlainDealer, May 28, 1983; Madeline Drexler, "Pride and Prejudice," Cleveland Plain-Dealer, August 11, 1985.

31. Letter from Ralph Veverka to Richard S. Marous, May 3, 1982, Minutes, Cleveland Cultural Garden Federation, Kay Wood Collection, Cleveland Cultural Gardens Federation Collection, unprocessed manuscript collection in author's possession, to be donated to Cleveland State University Archives; hereafter cited as Wood Collection; "City's neglect, Decay, Spoil Rockefeller Park," Cleveland Plain-Dealer, March 9, 1982; "Save Rockefeller Park," Cleveland Plain-Dealer, March 11, 1982; Madeline Drexler, "Pride and Prejudice," Cleveland Plain-Dealer, August 11, 1985.

32. Cleveland Cultural Garden Federation, Meeting Minutes, May 13, 1981, January 26, 1988, February 4, 1988, March 8, 1988, March 23, 1988, April 12, 1988, May 17, 1988, June 21, 1988, drawing February 1989, February 14, 1989, Minutes, CCGF, Wood Collection.

33. Letter from Alex Mark to the CCGF, November 2, 1984, Minutes, CCGF, Wood Collection; "About the Chinese Cultural Park in Cleveland," Nov. 1981, Wood Collection; "Cultural Garden Gift Withers in Storage," Cleveland Plain-Dealer, January 13, 1985; Oral history interview with Anthony Yen, Interview 800009, Cleveland Regional Oral History Collection, Department of History Cleveland State University.

34. City of Cleveland, Office of City Council, Archives, Cleveland Cultural Gardens Collection, Correspondence Regarding Yugoslav Garden, 1989-1993; for a history of the Njegosh statue, see $<$ http://siris-artinventories.si.edu/ipac20/ipac.jsp? \& profile=all\&source $=\sim$ ! siartinventories\&uri=full =3100001 !315516 !0\#focus> (October 1, 2009); on commemorative activities at St. Sava Serbian Orthodox Cathedral, where the bust of Njegosh was relocated, see William F. Miller, "Serbian Churches Honor World War II General," Cleveland Plain-Dealer, July 13, 1997.

35. Oral history interview with Lena Pogrebinsky by Jessica Puerta, 22 October 2002, Interview 800016, Cleveland Regional Oral History Collection, Department of History Cleveland State University; for a summary of the turnaround, Steve Litt, "Gardens Merit Our Attention," Cleveland Plain-Dealer, August 21, 2008. 